Jurnal Inkofar * Volume 5 No. 1, Juli 2021 * E-ISSN: 2581-2920

Tersedia secara online di: http://www.politeknikmeta.ac.id/meta/ojs/

\title{
ANALISIS FAKTOR YANG MEMPENGARUHI PENGOLAHAN LIMBAH KAKAO MENJADI PAKAN TERNAK DI PT BERAU COCOA, KALIMANTAN TIMUR
}

\author{
Anthonius Dhinar ${ }^{1}$, Hamim Rachman ${ }^{2}$ \\ ${ }^{1}$ Teknologi Rekayasa Logistik / Teknik Industri / Politeknik Sinar Mas Berau Coal / \\ adhinar1393@gmail.com \\ ${ }^{2}$ Teknologi Rekayasa Logistik / Teknik Industri / Politeknik Sinar Mas Berau Coal / \\ hamimrachman@gmail.com
}

\begin{abstract}
Waste is the residual product from an industrial process and the household, useless, no economic value and is a serious problem in the industrial era 4.0, and become an important issue of environmentally friendly industrialization regulations. Primary industries such as sugar cane, oil palm, cocoa produce a lot of wastes during the pre-harvest period such as leaves and three litters, and in the post-harvest period such as pulp, fruit skins, and fruit pulp. PT Berau Cocoa processes cocoa skin waste into animal feed which is applied to cattle in Binungan. This research uses a descriptive research method and how to teach data by distributing 50 questionnaires to cocoa farmers. The results of data analysis show the fact that most cocoa farmers are male of 38 peoples (76\%), high school education level of 33 peoples (82\%), joined along 4-6 years as 45 peoples (90 $\%)$, all respondents are married, and own private land. Supporting factors that influence the processing of cocoa waste into animal feed can be seen from the average value of each factor, method factor (0.596), material factor (0.512), human factor (0.416), and money factors (0.404), and the lowest average is the engine factor (0.312).
\end{abstract}

Keywords : 5M, chocolate, factor analysis, industry, cocoa waste, animal feed

\begin{abstract}
ABSTRAK
Limbah merupakan produk akhir/sisa hasil dari suatu proses baik industri dan rumah tangga dianggap menjadi bahan yang tidak berguna, tidak memiliki nilai ekonomi, menjadi persoalan serius di era industri 4.0 dan menjadi isu penting regulasi industrialisasi ramah lingkungan. Industri primer seperti perkebunan tebu, kelapa sawit, kakao banyak menghasilkan limbah saat masa pra-panen seperti daun dan seresah pohon, dan masa pasca-panen seperti pulp, kulit buah, dan daging buah. PT Berau Cocoa mengolah limbah kulit kakao menjadi pakan ternak sapi yang ada di Binungan. Metode pada penelitian ini adalah metode penelitian deskriptif dan cara pengumpulan data yaitu membagikan 50 lembar kuesioner ke para petani kakao binaan PT Berau Cocoa. Hasil analisis data menunjukkan karakteristik petani kakao paling banyak yaitu jenis kelamin laki-laki sebanyak 38 orang (76\%), tingkat pendidikan SMA sebanyak 33 orang (82\%), sudah bergabung dengan PT Berau Cocoa selama 4-6 tahun sebanyak 45 orang (90\%), semua responden sudah menikah, dan memiliki lahan pribadi. Faktor pendukung yang mempengaruhi pengolahan limbah kakao menjadi pakan ternak dilihat dari nilai rata-rata setiap faktor yaitu faktor metode $(0,596)$, material $(0,512)$, manusia $(0,416)$, dan faktor uang $(0,404)$, sedangkan kategori faktor yang memiliki rata-rata terendah adalah faktor mesin $(0,312)$.
\end{abstract}

Kata Kunci : 5M, faktor analisis, industri, limbah kakao, pakan ternak

\section{PENDAHULUAN}

Limbah merupakan produk akhir, buangan atau sisa hasil dari suatu proses baik industri maupun rumah tangga yang dianggap menjadi bahan yang tidak berguna dan tidak memiliki nilai ekonomi, menjadi persoalan serius di era industri 4.0 yang harus segera ditangani, apalagi regulasi tentang industrialisasi ramah lingkungan menjadi isu penting (Basaran, 2013; Wilson, et al., 2012). 
Dalam era industri 4.0, berkembang sebuah pandangan/paradigma pembangunan yang berkelanjutan (sustainable development) yang dikaitkan dengan terbitnya isu manajemen lingkungan dalam bentuk penerbitan sertifikat ISO 14000 yang menekankan pada pengelolaan sumber daya alam yang efektif dan efisien dengan meminimalkan dampak negatif terhadap lingkungan di sekitarnya. Tiga pilar utama pembangunan berkelanjutan yaitu ekonomi, ekologi, lingkungan dan sosial. Secara ekonomi, pembangunan industri harus dapat menciptakan pertumbuhan yang tinggi untuk mencapai kesejahteraan, khususnya bagi stakeholder. Secara ekologi, pembangunan hendaknya menekan seminimal mungkin dampak lingkungan yang ditimbulkan oleh kegiatan pengelolaan sumber daya alam, sedangkan secara sosial dapat memberikan manfaat yang luas bagi masyarakat.

Industri primer seperti perkebunan tebu, kelapa sawit, karet, kakao dll banyak menghasilkan limbah. Limbah yang dihasilkan bisa berasal saat masa pra-panen seperti daun dan seresah pohon, dan limbah saat masa pasca-panen seperti pulp, kulit buah, dan daging buah. (Kristanto, 2004).

Berdasarkan Data Kabupaten Berau Dalam Angka 2020, Kabupaten Berau memiliki potensi kakao yang termasuk 3 terbesar penyumbang devisa/pendapatan daerah hasil alam yaitu sebesar 661.140 ton tahun 2018 yang berada di Kabupaten Berau dan juga terdapat sebuah Pabrik Pengolahan buah kakao yang bernama PT Berau Cocoa yang bergerak dalam mengembangkan budidaya Kabupaten tanaman kakao sehingga dapat dimanfaatkan masyarakat untuk meningkatkan nilai tambah hasil panen para petani kakao di wilayah tersebut. Pengolahan limbah harus dilakukan dari awal sampai akhir atau lebih dikenal dengan sebutan hulu sampai hilir karena jika ini tidak dilakukan maka terdapat ancaman berupa pencemaran yang akan berakibat fatal (Xue, et al., 2013; Mohanty, 2012). Pengolahan limbah kakao sangat perlu dilakukan karena tanaman tersebut secara umum hanya dimanfaatkan bagian bijinya saja tetapi bagian lainnya hanya menjadi sisa buangan atau limbah. Limbah kulit kakao dapat diolah menjadi Adsorben Zat Warna Rhodamin B (Hening Purnamawati, 2014), Proses Sintesis Material HPNc/MnO2 sebagai Elektroda Superkapasitor (Zulkaisi dkk, 2019), Pemanfaatan Kulit Buah Kakao Fermentasi Sebagai Alternatif Bahan Pakan Nabati Serta Pengaruhnya Terhadap Pertumbuhan Ternak Entok (Cairina muschata) (Marlina Kamelia dan Fathurohman , 2017) sedangkan langkah yang dilakukan oleh PT Berau Cocoa sendiri untuk mengatasi limbah tersebut adalah melakukan pengolahan limbah pasca-panen menjadi pakan ternak sapi yang ada di Binungan.

\section{STUDI PUSTAKA}

Faktor-Faktor yang berpengaruh terhadap Kompetensi Petani Kakao di Provinsi Sulawesi Tengah mengambil kesimpulan bahwa tingkat kompetensi petani kakao rendah disebabkan oleh lemahnya kekosmopolitan dan lemahnya peran penyuluh sebagai komunikator, advisor, dinamisator, motivator, organisator dan edukator (Andri dkk, 2019). Upaya untuk meningkatkan lemahnya kompetensi petani membutuhkan perbaikan tingkat kekosmopolitan dan peran penyuluh sebagai komunikator, advisor, dinamisator, motivator, organisator dan edukator.

Percepatan Inovasi Limbah Coklat sebagai Pakan Ternak Kambing Ettawa di Kecamatan Tanjung Baru mengambil kesimpulan kecepatan atau selang waktu yang dibutuhkan peternak di Kecamatan Tanjung Baru Kabupaten Tanah Datar adalah cepat (kurang dari 1 minggu) dengan persentase $66,67 \%$. Luas penerapan inovasi atau proporsi jumlah ternak yang telah diberi inovasi baru di Kecamatan Tanjung Baru Kabupaten Tanah Datar diterapkan sebesar 76,67\% (Anas dkk, 2017). Mutu intensifikasi dengan membandingkan penerapan dengan rekomendasi yang disampaikan oleh penyuluh di Kecamatan Tanjung Baru yaitu sebanyak 73,33\% peternak menjawab baik.

Tujuan dilakukannya dalam penelitian ini antara lain melihat karakteristik petani kakao binaan PT Berau Cocoa, dan mengetahui faktor-faktor pendorong dan penghambat yang mempengaruhi pengolahan limbah kakao menjadi pakan ternak dimana bisa berasal dari man (manusia), method 
(metode), material (bahan baku atau barang jadi), money (uang), dan machine (mesin) sehingga dapat dilakukan perbaikan (improvement) faktor penghambat dan meningkatkan dan menjaga faktor yang sudah baik.

\section{HASIL, ANALISA DATA DAN PEMBAHASAN}

Karakteristik petani kakao paling banyak yaitu jenis kelamin laki-laki sebanyak 38 orang (76\%), tingkat pendidikan SMA sebanyak 33 orang (82\%), sudah bergabung dengan PT Berau Cocoa dengan waktu 4-6 tahun sebanyak 45 orang (90\%), semua responden sudah menikah, dan sifat kepemilikan lahan adalah milik pribadi.

\subsection{Karakteristik petani berdasarkan jenis kelamin}

Dari 50 data responden yang valid dan lengkap, maka peneliti mendapatkan banyaknya responden dan prosentase untuk masing-masing variabel jenis kelamin. Hasil tersebut dapat dilihat pada Gambar 1.

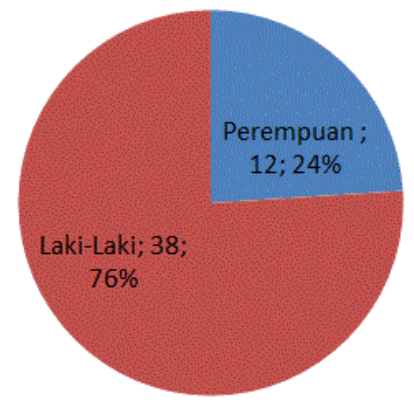

\section{Gambar 1. Karakteristik petani berdasarkan jenis kelamin}

Berdasarkan rangkuman jumlah dan prosentase petani coklat pada 2 Kampung yaitu Suaran dan Meraang-Tumbit Melayu diketahui karakteristik variabel jenis kelamin terbanyak yaitu laki-laki sebanyak 38 petani dengan prosentase sebesar $76 \%$, dan petani dengan jenis kelamin perempuan berjumlah 12 orang dengan prosentase sebesar $24 \%$.

\subsection{Karakteristik petani berdasarkan tingkat Pendidikan}

Dari 50 data responden yang valid dan lengkap, maka peneliti mendapatkan banyaknya responden dan prosentase untuk masing-masing variabel tingkat pendidikan. Hasil tersebut dapat dilihat pada Gambar 2.

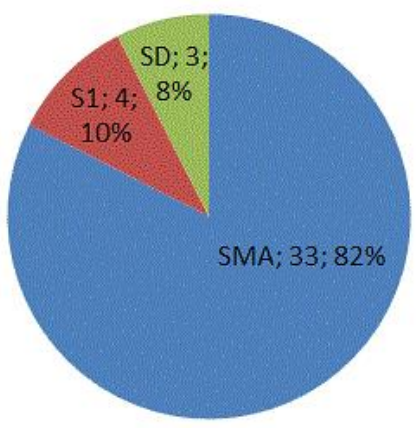

\section{Gambar 2. Karakteristik petani berdasarkan Tingkat Pendidikan}

Jumlah dan prosentase responden petani Coklat pada 2 Kampung yaitu Suaran dan MeraangTumbit Melayu diketahui karakteristik variabel pendidikan SMA yaitu sebanyak 33 orang atau sebesar 82\%, responden dengan tingkat pendidikan S1 berjumlah 4 orang atau sebesar $10 \%$, sedangkan responden terendah memiliki tingkat pendidikan SD yaitu sebanyak 3 orang atau sebesar $8 \%$. 


\subsection{Karakteristik petani berdasarkan lama bergabung dengan PT Berau Coal}

Dari 50 data responden yang valid dan lengkap, maka peneliti mendapatkan banyaknya responden dan prosentase untuk masing-masing variabel Lama bergabung dengan PT Berau Cocoa. Hasil tersebut dapat dilihat pada Gambar 3.

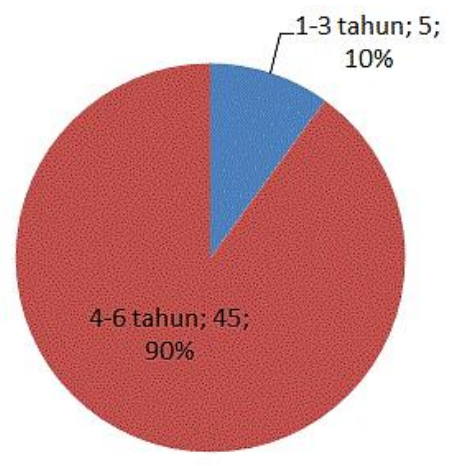

\section{Gambar 3. Karakteristik petani berdasarkan Lama bergabung dengan PT Berau Cocoa}

Jumlah dan prosentase responden petani Coklat pada 2 Kampung yaitu Suaran dan MeraangTumbit Melayu diketahui karakteristik variabel Lama bergabung dengan PT Berau Cocoa diketahui bahwa responden terlama yaitu dengan waktu 4-6 tahun sebanyak 45 orang atau sebesar $90 \%$ dan responden dengan waktu 1-3 tahun sebanyak 5 orang atau sebesar $10 \%$.

\subsection{Karakteristik petani berdasarkan lama menjadi petani kakao}

Dari 50 data responden yang valid dan lengkap, maka peneliti mendapatkan banyaknya responden dan prosentase untuk masing-masing variabel Lama menjadi petani kakao. Hasil tersebut dapat dilihat pada Gambar 4.

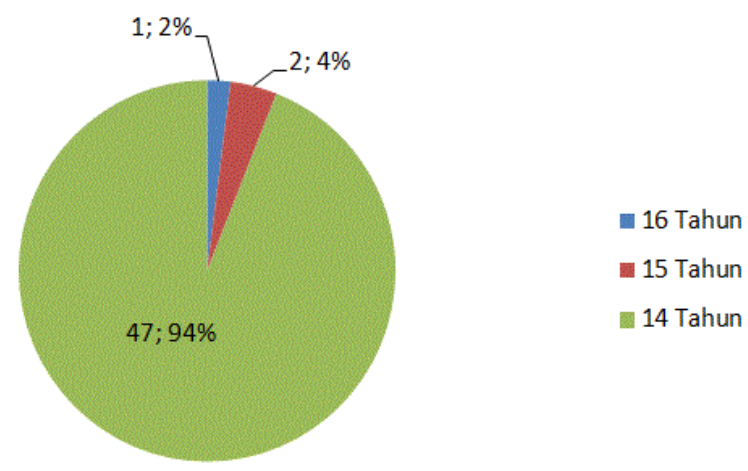

\section{Gambar 4. Karakteristik petani berdasarkan Lama menjadi petani kakao}

Jumlah dan prosentase responden petani Coklat pada 2 Kampung yaitu Suaran dan MeraangTumbit Melayu diketahui dengan karakteristik variabel Lama menjadi petani kakao diketahui bahwa responden terbanyak yaitu dengan waktu 14 tahun yaitu sebanyak 47 orang atau sebesar 94\% dan responden paling sedikit dengan waktu 16 tahun yaitu sebanyak 1 orang atau sebesar $2 \%$.

\subsection{Karakteristik petani berdasarkan status perkawinan}

Dari 50 data responden yang valid dan lengkap, maka peneliti mendapatkan banyaknya responden dan prosentase untuk variabel Status Perkawinan. Hasil tersebut dapat dilihat pada Gambar 5. 


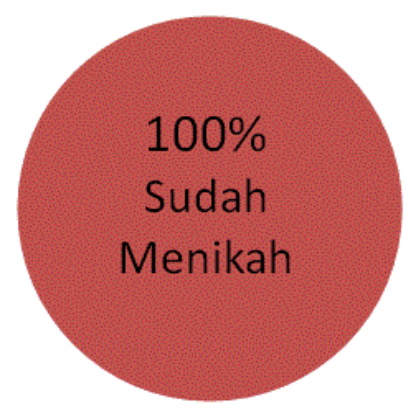

\section{Gambar 5. Karakteristik petani berdasarkan petani berdasarkan Status Perkawinan}

Jumlah dan prosentase petani Coklat pada 2 Kampung yaitu Suaran dan Meraang-Tumbit Melayu diketahui bahwa responden variabel Status Perkawinan yaitu sebanyak 50 orang sudah menikah.

\subsection{Karakteristik petani berdasarkan kepemilikan lahan}

Dari 50 data responden yang valid dan lengkap, maka peneliti mendapatkan banyaknya responden dan prosentase untuk variabel kepemilikan lahan. Hasil tersebut dapat dilihat pada Gambar 6.

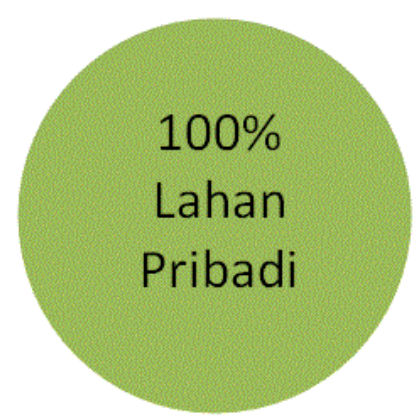

Gambar 6. Karakteristik petani berdasarkan petani berdasarkan kepemilikan lahan

Jumlah dan prosentase petani Coklat pada 2 Kampung yaitu Suaran dan Meraang-Tumbit Melayu diketahui bahwa responden variabel kepemilikan lahan yaitu sebanyak 50 orang memiliki lahan pribadi.

Tabel 1. Total Nilai Rata-Rata (Mean) dan Rank

\begin{tabular}{|c|c|c|c|c|c|c|}
\hline No & Faktor & $\begin{array}{c}\text { Pertanyaan } \\
\text { (X) }\end{array}$ & $\begin{array}{c}\text { Jumlah } \\
\text { responden } \\
\text { yang } \\
\text { menjawab } \\
\text { (orang) } \\
\end{array}$ & $\begin{array}{c}\text { Nilai rata-rata } \\
\text { (Mean) per } \\
\text { pertanyaan }\end{array}$ & $\begin{array}{c}\text { Total Nilai rata- } \\
\text { rata (Mean) } \\
\text { Group Faktor }\end{array}$ & Rank \\
\hline \multirow{5}{*}{1} & \multirow{5}{*}{ Man } & $\mathrm{X} 1$ & 40 & 0,80 & \multirow{5}{*}{0,416 atau $41,6 \%$} & \multirow{5}{*}{3} \\
\hline & & $\mathrm{X} 2$ & 50 & 1,00 & & \\
\hline & & $\mathrm{X} 3$ & 4 & 0,08 & & \\
\hline & & $\mathrm{X} 4$ & 6 & 0,12 & & \\
\hline & & $\mathrm{X} 5$ & 4 & 0,08 & & \\
\hline \multirow{5}{*}{2} & \multirow{5}{*}{ Machine } & $\mathrm{X} 1$ & 50 & 1,00 & \multirow{5}{*}{0,312 atau $31,2 \%$} & \multirow{5}{*}{5} \\
\hline & & $\mathrm{X} 2$ & 6 & 0,12 & & \\
\hline & & X3 & 10 & 0,20 & & \\
\hline & & $\mathrm{X} 4$ & 4 & 0,08 & & \\
\hline & & $\mathrm{X} 5$ & 8 & 0,16 & & \\
\hline \multirow{4}{*}{3} & \multirow{4}{*}{ Money } & $\mathrm{X} 1$ & 49 & 0,98 & \multirow{4}{*}{0,404 atau $40,4 \%$} & \multirow{4}{*}{4} \\
\hline & & $\mathrm{X} 2$ & 4 & 0,08 & & \\
\hline & & $\mathrm{X} 3$ & 4 & 0,08 & & \\
\hline & & $\mathrm{X} 4$ & 40 & 0,8 & & \\
\hline
\end{tabular}


Jurnal Inkofar * Volume 5 No. 1, Juli 2021 * E-ISSN: 2581-2920

Tersedia secara online di: http://www.politeknikmeta.ac.id/meta/ojs/

\begin{tabular}{|c|c|c|c|c|c|c|}
\hline & & $\mathrm{X5}$ & 4 & 0,08 & & \\
\hline \multirow{5}{*}{4} & \multirow{5}{*}{ Methode } & $\mathrm{X} 1$ & 39 & 0,78 & \multirow{5}{*}{0,596 atau $59,6 \%$} & \multirow{5}{*}{1} \\
\hline & & $\mathrm{X} 2$ & 4 & 0,08 & & \\
\hline & & $\mathrm{X} 3$ & 50 & 1,00 & & \\
\hline & & X4 & 50 & 1,00 & & \\
\hline & & $\mathrm{X} 5$ & 6 & 0,12 & & \\
\hline \multirow{5}{*}{5} & \multirow{5}{*}{ Material } & $\mathrm{X} 1$ & 40 & 0,80 & \multirow{5}{*}{0,512 atau $51,2 \%$} & \multirow{5}{*}{2} \\
\hline & & $\mathrm{X} 2$ & 6 & 0,12 & & \\
\hline & & $\mathrm{X} 3$ & 2 & 0,04 & & \\
\hline & & $\mathrm{X} 4$ & 40 & 0,80 & & \\
\hline & & $\mathrm{X} 5$ & 40 & 0,80 & & \\
\hline
\end{tabular}

Berdasarkan nilai mean rank diatas terlihat bahwa kategori 1 yaitu faktor metode dengan nilai sebesar 0,596 (59,6\%), kategori 2 yaitu faktor material atau bahan baku dengan nilai sebesar 0,512 $(51,2 \%)$, kategori 3 yaitu faktor manusia dengan nilai sebesar 0,416 (41,6\%), kategori 4 adalah faktor uang dengan nilai rata-rata sebesar $0,404(40,4 \%)$ dan kategori 5 yaitu faktor mesin dengan nilai rata-rata sebesar 0,312 (31,2\%). Faktor Metode menjadi fokus utama untuk dilakukan yaitu dengan melakukan langkah-langkah perbaikan mengenai cara penyuluhan dan mengoptimalkan peran penyuluh sebagai komunikator, advisor, dinamisator, motivator, organisator dan edukator kepada petani binaan PT Berau Cocoa dengan menggandeng kerjasama Dinar Perkebunan dan Pertanian serta Dosen dari Instansi Pendidikan yang terkait.

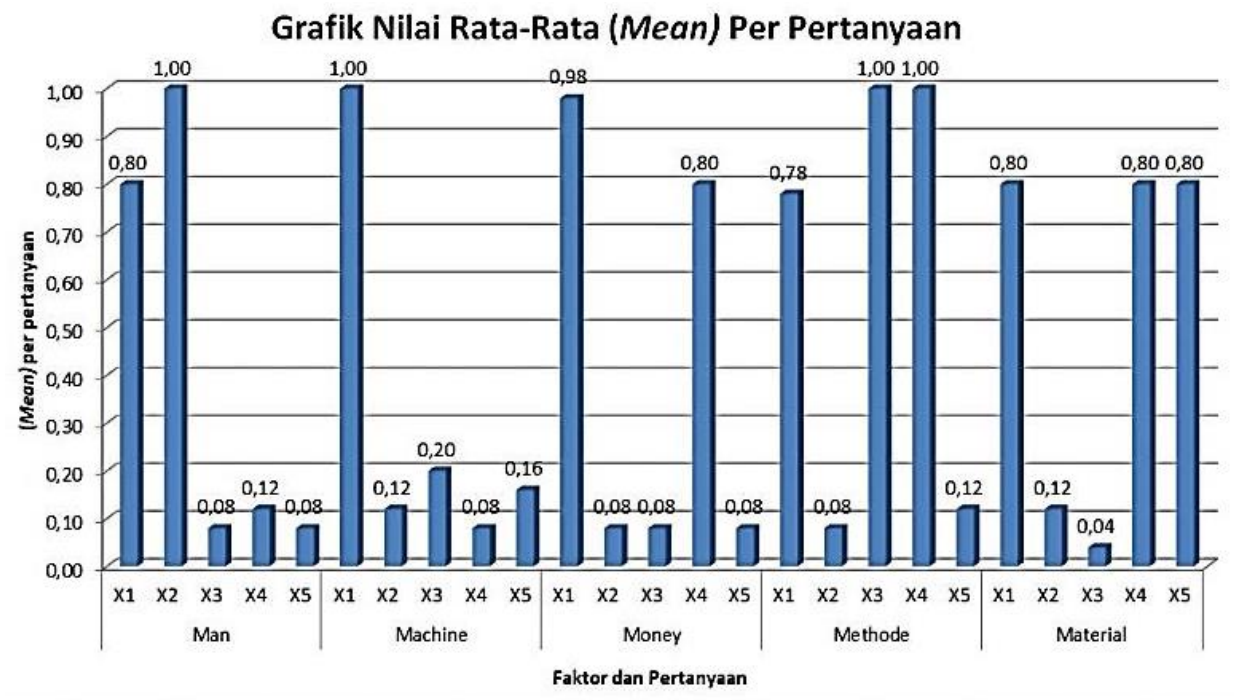

Gambar 7. Grafik Nilai Rata-Rata (Mean) Per Pertanyaan

GRAFIK NILAI TOTAL RATA-RATA (MEAN)

5 FAKTOR

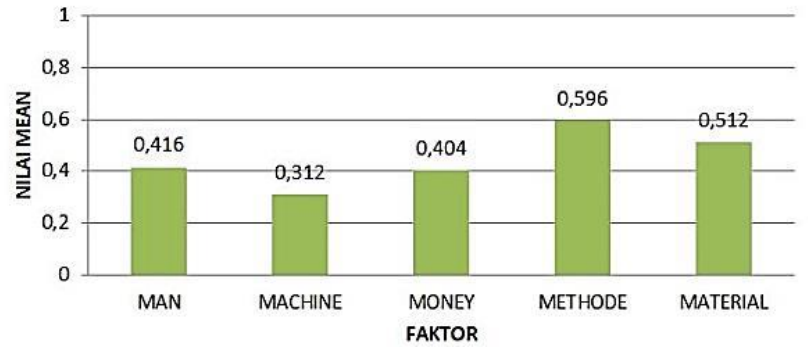

Gambar 8. Grafik Nilai Total Rata-Rata (Mean) 5 Faktor 
Jurnal Inkofar * Volume 5 No. 1, Juli 2021 * E-ISSN: 2581-2920

Tersedia secara online di: http://www.politeknikmeta.ac.id/meta/ojs/

\section{KESIMPULAN}

Berdasarkan penelitian yang telah dilakukan maka didapatkan kesimpulan pertama yaitu tentang karekteristik petani coklat terbanyak yaitu jenis kelamin laki-laki sebanyak 38 responden atau sebesar $76 \%$, pendidikan SMA sebanyak 33 orang atau sebesar $82 \%$, sudah bergabung dengan PT Berau Cocoa dengan waktu terlama 4-6 tahun sebanyak 45 orang atau sebesar 90\%, memiliki status perkawinan sudah menikah yaitu sebanyak 50 orang dan sifat kepemilikan lahan adalah lahan milik pribadi yaitu sebanyak 50 orang. Kesimpulan kedua yaitu menegnai faktor pendukung serta faktor penghambat dalam pengolahan limbah kakao menjadi pakan ternak, maka peneliti mengambil kesimpulan yaitu faktor-faktor pendukung yang mempengaruhi pengolahan limbah kakao menjadi pakan ternak di Pabrik Berau Cocoa dengan nilai rata-rata (mean) diatas faktor mesin adalah faktor method $(0,596)$, faktor material $(0,512)$, faktor man $(0,416)$, dan faktor money $(0,404)$, sedangkan rank mean kategori faktor yang memiliki rata-rata (mean) terendah dengan nilai rata-rata pertanyaan terendah adalah X2, X3, X4 dan X5 yang terdapat pada Faktor Mesin (Machine) yaitu sebesar 0,312.

Dalam memberikan pemahaman dan pengetahuan tentang mesin, alat/peralatan pendukung dan kapasitas yang digunakan dalam proses pengolahan buah kakao, pengolahan kulit kakao (POD), proses fermentasi seperti kotak fermentasi dan proses packaging (pengemasan) kepada petani diperlukan Sosialisasi lebih mendalam dan berkala kepada petani mengenai langkah-Langkah proses pengolahan buah kakao menjadi berbagai macam bentuk produk turunan yang didalamnya terdapat bahan, mesin, alat/peralatan pendukung dan kapasitasnya masing-masing dan Diagram alir proses pengolahan kulit kakao (POD) dimulai dengan proses pengumpulan bahan baku, bahan dan proses fermentasi, produk setengah jadi dari limbah kulit kakao, penghalusan limbah kakao menjadi pupuk kompos, sampai dengan proses packaging (pengemasan) yang didalamnya terdapat bahan, mesin, alat/peralatan pendukung dan kapasitasnya masing-masing.

Dengan dilakukannya sosialisasi secara berkala diharapkan pemahaman petani akan seragam dan dapat mendukung dan meningkatkan faktor-faktor lain dalam 5M yaitu dengan menjadwalkan dan mengadakan tour kunjungan petani binaan ke area PT Berau Cocoa untuk melihat mesin, alat/peralatan pendukung dan kapasitas yang digunakan dalam proses pengolahan buah kakao, pengolahan kulit kakao (POD), proses fermentasi seperti kotak fermentasi dan proses packaging (pengemasan).

Hal-hal yang akan dilakukan terkait gagasan selanjutnya dalam penelitian ini adalah peneliti ingin melakukan peningkatan lokasi petani kakao lain di desa mitra binaan PT Berau Cocoa selain Suaran, Tumbit Dayak dan Tumbit Melayu (yang sudah di kunjungi) dan peneliti ingin melakukan peningkatan variabel yang diteliti menjadi 7M yaitu ditambahkan faktor Marketing dan Mother of Nature (Lingkungan/Environment).

\section{DAFTAR PUSTAKA}

Anas, A dkk.2017. Percepatan Inovasi Limbah Coklat Sebagai Pakan Ternak Kambing Ettawa Di Kecamatan Tanjung Baru. Jurnal Pertenakan Vol 14 No 2. ISSN1829-8729. Universitas Andalas.

Andri, dkk.2019. Faktor-Faktor Yang Berpengaruh Terhadap Kompetensi Petani Kakao Di Provinsi Sulawesi Tengah. Jurnal Penyuluhan, Maret 2019 Vol. 15 No. 1. Universitas Sintuwu Maroso, Poso.

Basaran, B.2013. What makes manufacturing companies more desirous of recycling? Management of Environmental Quality: An International Journal. 24 (1): 107- 122.

ISO 14000. Standar-Standar Terkait Pengelolaan Lingkungan

Kabupaten Berau Dalam Angka 2020. Penyedia Data untuk Perencanaan Pembangunan

Kamelia, M dan Fathurohman. (2017). Pemanfaatan Kulit Buah Kakao Fermentasi Sebagai Alternatif Bahan Pakan Nabati Serta Pengaruhnya Terhadap Pertumbuhan Ternak Entok 
(Cairina muschata). BIOSFER Jurnal Tadris Pendidikan Biologi Vol. 8 no.1 (2017) 6677.

Kristanto P.2004. Ekologi Industri. Jakarta: Penerbit Andi.

Purnamawati, H dan Utami, B. (2014). Pemanfaatan Limbah kulit kakao (Theobroma Cocoa L.) sebagai Adsorben Zat Warna Rhodamin B. Prosiding Seminar Nasional Fisika dan Pendidikan Fisika (SNFPF) Ke-5 2014. Volume 5 Nomor 12014 ISSN : 2302-7827.

Susila, H.2014. Analisis Faktor Penghambat Dan Pendukung Kontraktor Dalam Memahami Dokumen Kontrak Konstruksi. Jurnal Teknik Sipil dan Arsitektur. DOI: 10.36728/jtsa.v15i19.401.

Undang-Undang RI No. 18 Tahun 2008.

Wilson, D.C., Parker, D., Cox, J., Strange, K., Willis, P., Blakey, N., dan Raw, L.2012. Business waste prevention: A review of the evidence. Waste Management \& Research. 30 (9): 1728.

Xue, M., Li, J., dan Xu, Z. (2013). Management strategies on the industrialization road of state-of-the-art technologies for e-waste recycling: the case study of electrostatic separation: A review. Waste Management \& Research. 31 (2): 130-140.

\section{UCAPAN TERIMAKASIH}

Terimakasih kepada Bapak Kodim selaku Manager PT Berau Cocoa dan team yang telah membantu memberi arahan dan izin untuk melakukan penelitian ini.

Terimakasih kepada UPPM Politeknik Sinar Mas Berau Coal yang telah memberikan dana (hibah) internal sehingga penelitian ini dapat terealisasi.

Terimakasih kepada Program Studi Teknologi Rekayasa Logistik yang membantu proses dalam penelitian ini.

Terimakasih kepada para petani, dan team peneliti yang membantu proses dalam penelitian ini.

\section{LAMPIRAN}

Makalah ini dilengkapi dengan lampiran yang berisi beberapa gambar kegiatan penelitian yang dapat dilihat pada gambar 9 dan gambar 10.

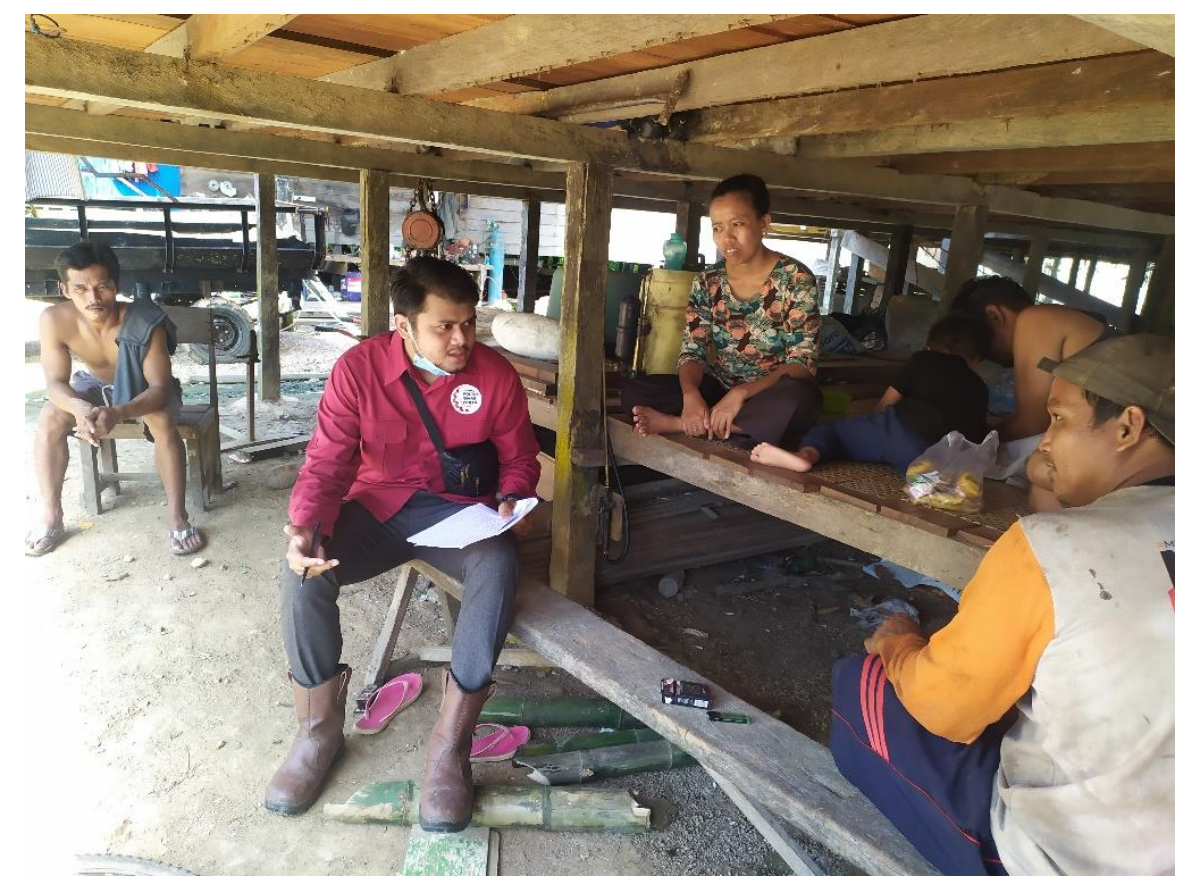

Gambar 9. Kegiatan pengisian kuesioner oleh responden yaitu Petani Kakao di Kabupaten Tumbit Melayu 
Jurnal Inkofar * Volume 5 No. 1, Juli 2021 * E-ISSN: 2581-2920

Tersedia secara online di: http://www.politeknikmeta.ac.id/meta/ojs/

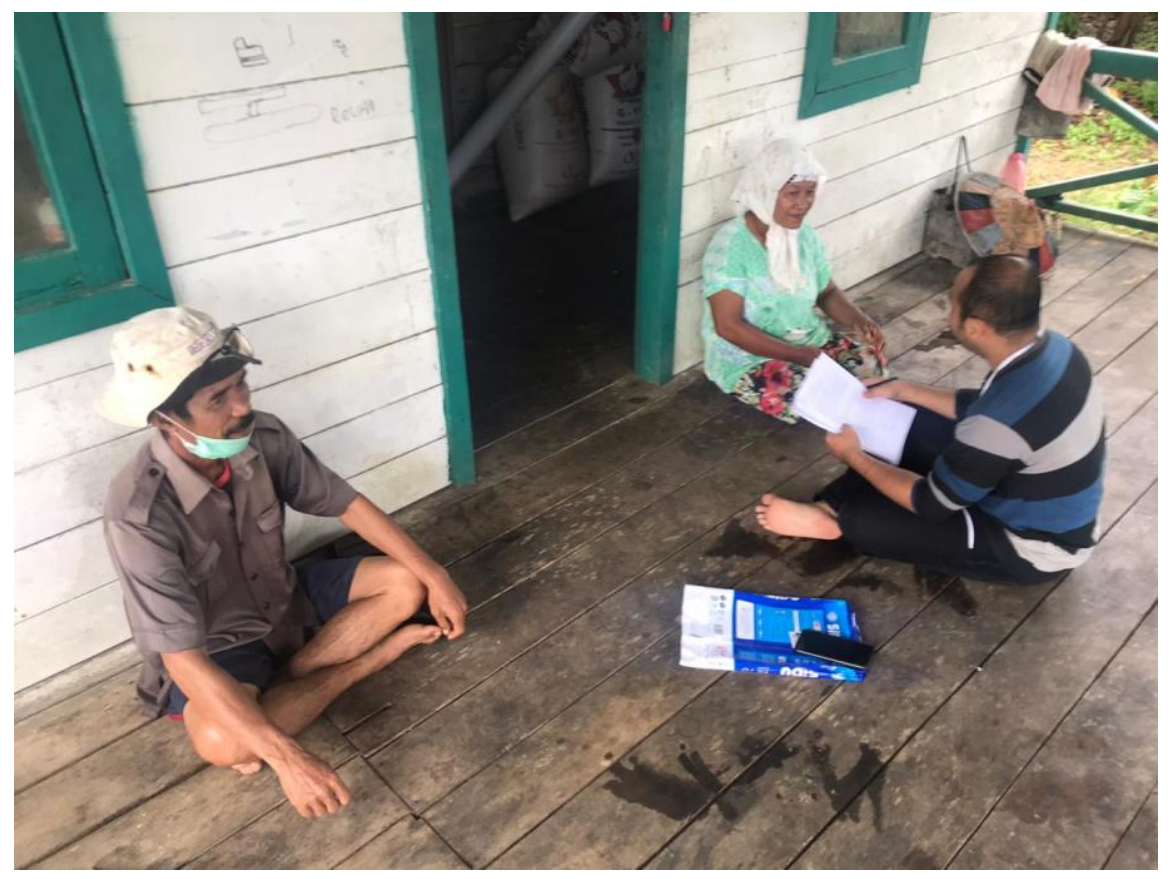

Gambar 10. Kegiatan pengisian kuesioner oleh responden yaitu Petani Kakao di Kabupaten Suaran 